\title{
Economic inequality according Atkinson
}

\author{
Barbora Wernerová ${ }^{1, *}$ \\ ${ }^{1}$ Institute of Technology and Business in České Budějovice, School of Expertness and Valuation, \\ Okružní 517/10, 37001 České Budějovice, Czech Republic
}

\begin{abstract}
Tony Atkinson is one of the most prominent academics. He devoted his life to studying and researching inequality. His work has led to the recognition of the economy of equality as a new economic sector. Atkinson tried to show that economics is primarily a social and moral science, which he promotes in his book The Economy of inequality. At present, inequality occupies an important place in public debate. Atkinson comes up with concrete proposals aimed at the existence of alternatives that will contribute to the struggle for social progress and equality. The aim of this paper is to introduce Atkinson's theory of economics of inequality, with emphasis on our global responsibility.
\end{abstract}

Key words: inequality, justice, equality, economy issues

\section{Introduction}

Inequality is a global problem that is related to a number of other dangerous factors. In this article I will attempt a theoretical, philosophical insight into the issue of inequality. One of Anthony Atkinson's main equality experts talks about the need for an overall view of inequality. We can not perceive inequality, for example, only from an economic point of view; on the contrary, we have to look for connections between different scientific disciplines. Inequality is one of today's most pressing problems in the social sphere. After World War II, it managed to keep it in check, but recently it has returned with great vehemence. Everyone knows about the extent of this problem, but little has been said so far about what can be done if we do not want to despair. Atkinson shows that the problem is not only that the rich are getting richer. We can not deal with poverty and the whole economy is changing in such a way that most people lose it. If we want to reduce inequality, we can not settle for simply imposing new taxes on the rich people who will fund existing programs. [1].

These factors include globalization, technology development, financial services growth, changes in payment standards, increasingly smaller trade union rights, and, last but not least, the breakdown of tax reallocation and transfer payments policy. From determining these factors, it may seem that inequality grows for reasons beyond which we have complete control, which would be a misconception. That is because globalization is the result of political, economic and social processes that are influenceable, as well as the direction of technology development. [10]. The aim of the paper is to analyze Atkinson's theory of inequality economics with an emphasis on global responsibility[5].

\footnotetext{
*Corresponding author: wenerova@mail.vstecb.cz
} 


\section{Theoretical approach to economic inequality}

\subsection{Justice}

This part of the paper focuses on the theoretical introduction of the concept of justice. Its philosophical basis is unforgettable. So what does the concept of justice mean? People have been asking this question since ancient times, and it is one of the most important virtues that relates to the other person. Plato has already included justice among the four cardinal virtues and emphasized its indispensable importance for the good functioning of social life. Aristotle saw justice as "good for others". The need for justice in society can still be perceived today. The role of justice has changed over the years in civil life, and its breakdown had to be categorized. Peter Fischer, in his article on Justice, states three meanings of justice. The oldest meaning of justice relates to being as a relation to one's own self. In this sense, justice is perceived as an individual property of physical equipment. The second meaning of justice is the relationship between me and society, which is manifested especially in relation to laws and treaties. The third meaning is the structure of human relationships where justice plays an important role in the relationship between the individual and society, with an emphasis on mutual obligations [6].

Liberal American political philosopher John Rawls sees justice as the fundamental virtue of social institutions. In his book Theory of Justice, Rawls puts a fundamental question on what principles of justice can people agree across all differences. Rawls sets the principles of justice as some kind of fair dealing, and he reveals these principles through an experiment in which he examines how things look before laws exist. This status is called primary, fairness is characterized by ignorance, because in the natural state nobody knows who they are, people do not know their social status, their prospects. At this point, people can act fairly - all to choose the options that will be fair for all and even for the most disadvantaged - people will be thinking about whether they are not the handicapped, the poor. And so logically they want laws that will be beneficial to them in all these conditions. This can be described as a hypothesis that, in the case of a person's ignorance of what he is and what life he will have, he will vote with caution and thought [13].

Principles of Rawls' Theory of Justice

1. Equal freedoms - the greatest possible freedom that does not endanger the freedom of others

2. Difference - the authorities are open to all and no one can be prevented from holding office (social and economic inequalities are organized to favor the most disadvantaged)

Rawls formulated what a fair society means in terms of institutions:

a) Social justice: serves to maintain society, it is layered, it is primarily redistribution

b) Legal justice: laws must apply equally to all

c) Exchange justice: it is at the individual level - it is much easier to act upon it than in an individual vs. state

d) Distributive justice: the relationship between the individual and society, the general good is superior to the good of an individual, the army is to fairly protect every citizen of the state, but it is very difficult to determine the degree of distributive justice (either equality: everyone equally or according to Aristotle: based on merit)[13].

Economists, like Atkinson, work with economic inequality that we can divide into vertical and horizontal. Economic justice mainly concerns tax issues. Vertical justice is defined as a fair approach to individuals of different social status, with the tax burden being derived from its income, which leads to progressive taxation. Against the principle of horizontal justice, 
the same tax burden is applied regardless of the particular economic environment. Individuals with the same income should therefore be equally tax-burdened [7].

\subsection{Equality}

If we talk about justice, we can not omit its connection to equality. Equality is a certain degree of identity between individuals. The essence of equality can be experienced in every sector of human life. All people are equal before the law, political equality allows us to vote and be elected, and equality of opportunity, which enables all citizens to gain social benefits [15]. Roger Scruton states the definition of the difference between equality and justice: "While it would be tautology to say that treating people fairly is just, it is definitely not tautology if we say it is fair to treat them impartially - although some people think so is. "[14].

Equality and justice are entities that manifest themselves in all aspects of life, and more than ever before, these concepts are fading away from civil life. Atkinson tries to speak about inequality not only in a narrow perspective, but presents a coherent theory that besides economics, also includes political philosophy, sociology, and the moral aspect of human decision-making. A hundred years ago economists solved justice from a wider perspective in a purely utilitarian spirit. Amartya Sen talks about utilitarianism as a theory focusing only on the sum of individual benefits as the least suitable for assessing inequality, since he lacks the interest in the interpersonal distribution of this amount [8].

\subsection{Inequality}

The term inequality can be explained from a mathematical point of view as a distinction between two or more particular characters, provided that these characters can be quantified. From another perspective, the notion of inequality by many people is perceived as a failure to achieve equal opportunities, which is determined by different circumstances that people can not influence [2].

The so-called fair average income $\left(\mathrm{y}_{\mathrm{e}}\right)$ is determined to calculate its value. Its definition is "evenly distributed income in a group that creates the same level of well-being as the current income distribution". This can be calculated as follows:

$$
\left(\frac{1}{n} \cdot \sum_{i=1}^{n} y_{i}^{1-s}\right)
$$

- yi corresponds to the balanced income of the i-th group

- e is the parameter of aversion of people to inequality

- $\mathrm{n}$ corresponds to the number of income groups

The aversion to inequality parameter tells about the degree of society's tolerance to egalitarianism. In theory, it may have the value of $<0 ; \infty)$. At zero, people are indifferent to the inequality, at the value $\infty$ society would only be interested in the one with the lowest income. You actually get values in the range of $<0.4 ; 3>$. The Atkinson's inequality point index is then calculated as follows: 


$$
I=1-\frac{y_{e}}{\mu}
$$

- $\mu$ corresponds to the current average income per person

Atkinson's index I may have the value of $<0 ; 1>$. The more you approach the average income in the group of fair average income in society, the closer I will be to zero, the more evenly the income distribution will be, even theoretically, at point 0 , totally uniform. On the other hand, in the direction to the value of 1 , income will be more and more inequal [9].

\subsection{Equal opportunities}

Equality of opportunity is a highly discussed phenomenon that has been addressed by leading economists in recent years.

Richard Tawney in his essay, Equality, presents a sample model of opportunity inequality that results from inequal initial opportunities. As an example, we can introduce a student who endeavors to be admitted to a medical school by studying, while another student is admitted to a medical school because of the influence of his parents. This is an opportunity inequality, but does it mean that we could consider the inequality of the results to be entirely irrelevant? [16].

Those who do not consider the inequality of the results as an important aspect hold the fact that we all should have set equal chances and the same starting conditions at the start of our lives. Atkinson refuses this thinking for three reasons. Atkinson says that ignoring the results would not only be illogical but especially unethical. Society should not ignore the individual, whose striving results in hardship, even though the preconditions for equality of opportunity are given. The importance of the results can be demonstrated in a sport analogy, when the unequal equality of opportunity states that we each have the same chances to fulfill our life plans independently of others. Congenial equality of opportunity shows us that we all have a chance to participate in the swimming race, but only one can win. Equality of results will play the role of future generations as the impact of family background on results depends on the strength of the relationship between background and results and on the level of inequality between the conditions of individual families. Atkinson states that if we are concerned about equal opportunities in the future, we need to be concerned about the inequality of the results right now[2].

Reducing inequality in results can serve as a means of reducing inequality in opportunities. The inequality of the results has a negative impact on the whole of today's society. The increase in inequality increases the lack of social cohesion, the increase of crime and generally the deterioration of the quality of health.

\section{Development of Atkinson's theory of inequality from the perspective of descriptive methods}

This part of the article focuses on the specifics of global inequality, which is closely related to the proposals for its reduction. Atkinson, as a major way of fighting inequality, identifies development aid and accepting global responsibility, which is reflected in the ethical behavior of countries. To address the whole issue of global inequality is not possible in this scope of the member, but to emphasize the importance of the moral aspects of national decision-making processes. 


\subsection{Global Inequality}

Current research shows that 1.2 billion people still live on less than $\$ 1.25$ a day [12]. At present, 3 billion people live below the poverty line. Global inequality is greatly influenced by the existence of global poverty geographically concentrated in Sub-Saharan Africa (46.4\%). Global inequality fully reflects the issues of today's globalized world. Global poverty is unconscious for the consumer's way of life, causing 25,000 victims to daily suffer from hunger and poverty. The United Nations adopted the Millennium Development Goals (MDGs) in 2001 to fight for the economic, political and social stability of the world [4].

In 2015, the proportion of the poorest people in these countries is 14 percent. Worldwide, the number of people living in extreme poverty declined by more than half, from 1.9 billion in 1990 to 836 million in 2015. The situation has changed significantly since 2000 [11].

Atkinson emphasizes the role of historical experience from which we should draw. Thanks to today's modern methods, scientists have created clear and accurate statistics that need to be scrutinized so that we can fully trust them. It is necessary to rely on statistical data and to derive from it the challenge for the future development of global inequality, which poses other possible problems. One of the most effective ways of combating inequality is development aid. Development aid is also linked to our global responsibility, which is reflected not only in the ethical behavior of specific countries but also in numbers. When we talk about the ethical aspect of development aid, it is obvious to point out the paradoxical attitude of the Western world to developing countries. It is absolutely necessary for the Western world to be confronted with global inequality with regard to future economic, social and political developments. [3].

In 2005, Europe contributed 45 billion euro to development cooperation, accounting for more than half of global aid, supporting a total of 144 countries. The fundamental problem of the implementation of the development aid by the Western world is the fact that they were not entirely willing to liberalize their market with the developing countries' market. To reduce the level of global inequality, it is necessary to remove the tariff barriers that make developing countries pay up to twice as much as countries of the European Union.

In the following we can see the development of inequality according to the Gini coefficient. Inequality is measured by Gini's coefficient based on the recalculated disposable income of households (income after taxes and transfer payments). The coefficient in Sweden is $23 \%$, which can be compared with $59.4 \%$ in South Africa. [2]. 
Inequality economy (Gini's coefficient

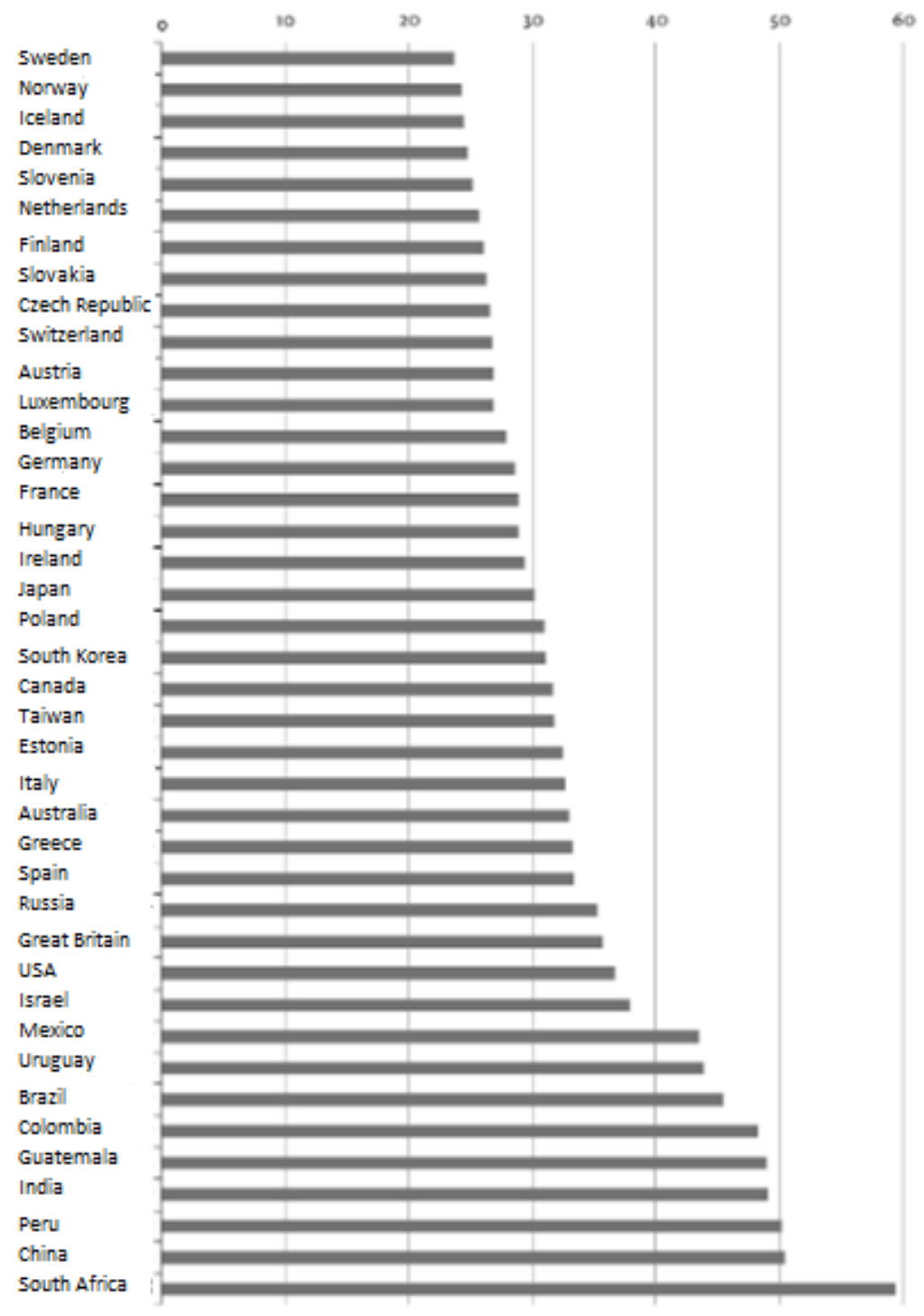

Fig. 1. LIS Key Figures

Source [17]. 


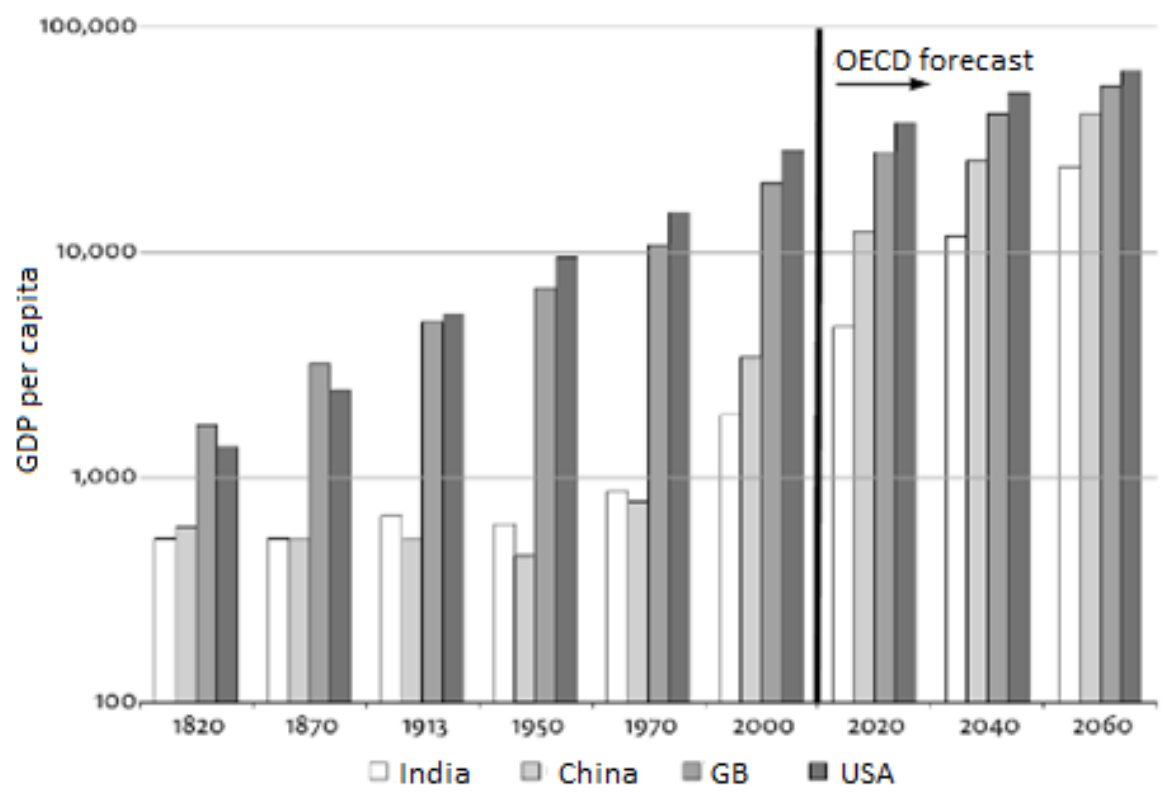

Fig. 2. Historical Statistics of the World Economy

Source: [18].

Global inequality reflects inequalities within and between countries.

\section{Proposal issues}

Atkinson comes up with specific proposals to significantly reduce inequality. It is not possible to include the whole text of Atkinson's proposals in this paper, but I will focus on the crucial role of capital income and the balance of ownership. Atkinson believes that most of the economic activities are carried out by a private sector that employs citizens and sells services and goods in the open market. This opinion relates to the importance of ownership as well as its control. In addition, Atkinson presents a revolutionary proposal on the wage code. The expanding wage gap is a major cause of deepening of the economic abyss. Atkinson supports the introduction of wage limits, which, according to him, reflects the company's ethical attitude. An example may be Mondragon Cooperative in Spain, which has cut managerial salaries to a maximum of 6.5 times the wage of the company's least paid employee. [2]

The introduction of wage limits British government has been discouraged by the British government following several objections. One of the main problems of wage limits is the differences between individual public authorities, depending on the nature of their workforce. Other objections included any motivation that could eventually lead the company management to remove employees with lower wages and replace them for example by outsourcing. The solution would be to raise the minimum wage threshold, which would have greater transparency, but would be redeemed by raising multiple minimum wages and increasing the maximum permitted maximum wages [2]. 
The introduction of the wage limit in the public sector would therefore lead to a lesser financial reward for senior officials in public administration. For the private sector, the introduction of wage limits would pose considerable problems, but on the other hand, wage councils would not have to address the fears of a dizzying rise in management salary. The principles of the wage code should regulate the difference between the top and the bottom of the ladders, and at the same time check that people are paid the same value for work corresponding to the same value. This topic is becoming more and more discussed and has a major impact on the future development of employee remuneration. In the course of years, employee salaries have become an individual matter that has led to a demographic fragmentation of companies and workplaces. It should be remembered that an alarming aspect is the company's offering of equal opportunities in the recruitment of employees, but the question remains whether or not it will actually be reflected in remuneration? Now, the notion of justice interferes with wage policy in terms of gender, ethnicity, or age. Atkinson also comes up with a warning about the declining tendency of gender equality and calls for a fair wage reward [3].

Atkinson's vision of the wage code includes great emphasis on the aspect of free will, which is reflected in the preference of a voluntary agreement that would be very difficult to achieve, but its changes would be more effective than the statutory control mechanisms. Atkinson also admits that change in the form of an agreement requires not only public support but, above all, the national debate on the widening of income from rising economic growth. The national discussion should include, in particular, an ethical approach to income policy and its transparency.

One of the other proposals to reduce inequality concerns guaranteed employment. According to Atkinson, the government should seek to reduce unemployment by creating jobs in the public sector for anyone interested in the job. Creating public employment for minimum wages addresses two issues at once. Today it is very popular way to employ citizens in so-called protected workshops where socially weaker people can realize their opportunities.

Atkinson's attempt to reduce inequality with his suggestions is undoubtedly a great achievement, which, as well as praise, does not avoid criticism either. To make Aktinson's proposals feasible, they should primarily include Rawls' theory of justice, which is almost impossible to apply to today's globalized world. Of course, specific steps in both social and political terms are feasible, but we should not forget the basic principle of good that every citizen must accept. Atkinson presents equality of opportunity as one of the proposals to reduce inequality, in which we can also see the absence of a fundamental lack of both theories. In both Rawls and Atkinson's theory, it is a utopian idea of the society's organization [3].

\section{Conclusion}

Atkinson's drive to reduce inequality in economic outputs leads in particular to the possibility of realizing equal opportunities that we can consider to be a major player in a democratic society. The functioning of democratic principles is unsustainable in the event of extreme inequality. For Atkinson, the notion of good society is incompatible with the current level of economic inequality. His book The Economics of inequality is progressive and tries to show ways that can effectively lead to economic equality. To help reduce inequality, we need to focus on analyzing distribution problems. Atkinson appeals to government officials to take action that would lead to the regulation of economically negative influences such as unemployment, poverty, globalization. Its action plan in the form of wage limits and an increase in gross national income for development aid from $0.7 \%$ to $1 \%$. 
The relationship between inequality and politics is very critical and will lead to fears of concentration of assets and income that lead to political power and influence. To reduce inequality, we need to work globally with the help of a new dialogue between nations. The issue of global inequality is a very topical issue that affects not only the economic but, above all, political situations. If we are talking about global inequality, we should be aware that it is also the global responsibility that every citizen of our country should feel. Global inequality coalesces as a result of individuals' choices, and so much awareness of the balance of freedom and moral responsibility, which is undoubtedly a civic right, is the foundation for creating a well-functioning society.

\section{References}

1. R. Aaberge, F. Bourguignon, F. Brandolini, Tony Atkinson and his Legacy, 63(3), (2017)

2. T. Atkinson, Ekonomika nerovnosti. Bizbooks - Albatros Media, (2016)

3. T. Atkinson, Inequality: What Can Be Done About It? [online], Available at: https://www.socialeurope.eu/inequality-can-done (2016)

4. M. Balabán, Perspektivy, tendence a hlavní aktéři vývoje bezpečnostní situace vesvětě do roku 2020. Sborník Bezpečnostni budoucnost České republiky. Otázky, výzvy, problémy, (2000)

5. C. J. Bennett, Ignorance, lotteries, and measure of economic inequality. Journal of economic inequality, 13(2), (2015)

6. P. Fischer, O spravedlnosti. Spor o spravedlnost, Filosofia, Praha, (1997)

7. M. Hrubec, John Rawls (1921-2002). Filosofický časopis, 50(6), 1047-1051, (2002)

8. M. Hrubec, Za Robertem Nožíčkem. Filosofický časopis, 50(2), 333-334, (2002)

9. J. Júlek, J. Moravcová, Ekonomické a sociální indikátory: od statistik k poznatkưm. Prague: Futura, (2007)

10. V. Labudová, Income Inequality Measures. Conference on Inequality and Proverty in the European Union and Slovakia, 107-112, (2012)

11. OSN, Informační centrum OSN v Praze [online], Available at: http://www.osn.cz/mdgs2015-fakta/ (2015)

12. OSN, Millenium Development Goals Report, (2014)

13. J. Rawls, Teorie spravedlnosti. Prague: Victoria Publishing, (1995)

14. R. Scruton, Slovník politického myšlení. Atlantis, (1999)

15. B. H. Sutor, Politická etika. Oikoymenh, (1996)

16. R. Tawney, Equality, (1998)

17. Inequality \& Poverty, Employment by Gender, Cross-National Data Center in Luxembourg [online]. Available at: http:/www.lisdatacenter.org/data-access/keyfigures/download-key-figures/ (2018)

18. Angus Maddison, University of Groningen [online]. Available at: http://www.ggdc.net/maddison/oriindex.htm (2018) 